\title{
CLINICAL RELEVANCE OF PRECORE MUTATIONS OF HEPATITIS B VIRUS IN CHRONIC LIVER DISEASE
}

\author{
Chaloska Ivanova Viktorija, ${ }^{1}$ Koloska Valentina, ${ }^{2}$ Genadieva Dimitrova Magdalena, ${ }^{1}$ \\ Todorovska Beti, ${ }^{1}$ Curakova Elena ${ }^{1}$ \\ ${ }^{1}$ University Clinic of Gastroenterohepatology, Clinical Centre, Skopje, Republic of Macedonia \\ ${ }^{2}$ Institute of Clinical Biochemistry, Clinical Centre, Skopje, Republic of Macedonia
}

Prihvaćen/Accepted 12. 05. 2014. god.

\begin{abstract}
Introduction: Hepatitis B is one of the most frequent etiological factors for chronic liver diseases worldwide. Recent studies have suggested the important role of the genetic diversity of the virus on natural course of hepatitis B. Hepatitis B e-antigen negative type of chronic hepatitis is associated with mutations in the precore region and basic core promoter of hepatitis B viral genome. Aim of study was to identify precore mutations in viral genome of patients with chronic hepatitis B and to evaluate clinical patterns of liver disease related to this type of hepatitis B. Methods: Sixty seven patients with hepatitis B were included in the study. In order to evaluate the clinical patterns of chronic liver disease related to hepatitis B viral infection, biochemical and virological investigations were done, as well as a quantification of serum viral load. All patients underwent liver biopsy and semiquantification of necroinflammation and/or fibrosis according to Knodell scoring was done. In the group of e antigen-negative patients, molecular analysis was performed in order to identify presence of mutations in precore region of the virus. Results: Study group was divided in $25 \mathrm{HBeAg}$-positive and $42 \mathrm{HBeAg}$-negative subjects. Alanin-aminotransferase activity and level of viral load were higher in HBeAg-positive $(\mathrm{p}<0.05)$, but average age and histology activity index were significantly higher in the HBeAg-negative patients $(p<0.01)$. Precore mutants were found in 38 of 42 patients with HBeAg-negative hepatitis (90\%). Fibrosis was found in 30/38 cases with mutations. Discussion: Mutations in precore region of $\mathrm{HBV}$ in $\mathrm{HBe} A g$-negative patients were more prevalent in older age and were associated with higher rate of fibrosis in liver tissue, meaning more advanced stage of the disease. This could be a consequence of longer duration of HBV infection or more
\end{abstract}

severe clinical course of the disease. Conclusion: Our results suggest that precore mutations are highly responsible for the development of hepatitis B e antigen-negative chronic liver disease in our patients. These mutations are associated with more progressive liver disease and with older age of the patients.

Key words: Hepatitis B virus, HBeAg, HBV DNA, precore mutant, chronic active hepatitis $\mathrm{B}$.

\section{INTRODUCTION}

Hepatitis B virus is a global health problem. The prevalence of $\mathrm{HBV}$ infection and patterns of transmission vary greatly through the world. Hepatitis B virus (HBV) infection may be associated with a very large spectrum of clinical presentations that may vary with age and the immunological status (1). The clinical spectrum of HBV infection ranges from subclinical to acute symptomatic hepatitis, or, rarely, fulminant hepatitis during the acute phase and from inactive hepatitis B surface antigen (HBsAg) carrier state, chronic hepatitis of various degree of histologic severity to cirrhosis and its complications during the chronic phase $(2,3)$.

Hepatitis B virus is a typical non-cytopathic virus that induces tissue damage of variable severity by stimulating a protective immune response that can simultaneously cause damage and protection by curing intracellular virus through the destruction of virus infected cells. Infected hepatocytes by the virus tolerate the infection very well and they are usually not damaged by the virus. Hence many patients can sustain very high amounts of replicating virus without any significant liver injury (immunotolerant state) (4). Hepatitis B is an immune - based disorder in which the extent of disease is profoundly influenced by the depth of the host immunologic response. 
Chronic hepatitis B afflicts nearly 400 million people worldwide (endemic areas include Asia and sub-Saharan Africa) and 1.25 million (predominantly males) in the United States. It may be noted as a continuum of acute hepatitis or diagnosed because of persistently elevated aminotransferase levels (5).

Early in the course, HBeAg and HBV DNA are present in serum, indicative of active viral replications and necroinflammatory activity in the liver. Immune clearance heralds biochemical improvement and coincides with disappearance of $\mathrm{HBeAg}$ and reduced HBV DNA levels $\left(<10^{5}\right.$ copies $\left./ \mathrm{mL}\right)$ in serum, appearance of anti-HBe, and integration of the HBV genome into the host genome in infected hepatocytes (6). If cirrhosis has not yet developed, such persons enter the inactive HBsAg carrier state and are at a low risk for cirrhosis and hepatocellular carcinoma (7). CHB can be broadly divided into two major forms - namely, hepatitis B virus e antigen ( $\mathrm{HBe} \mathrm{Ag}$ ) positive and $\mathrm{HBeAg}$ negative (8). Hepatitis B e antigen ( $\mathrm{HBeAg}$ ) negative CHB is also referred to as antiHBe positive and precore mutant hepatitis. Patients with $\mathrm{HBeAg}$ negative $\mathrm{CHB}$ have a naturally occurring mutant form of HBV that does not produce $\mathrm{HBeAg}$ because of a mutation in the precore or core promoter region of the $\operatorname{HBV}$ genome $(9,10)$. The most frequent precore mutation is a $\mathrm{G} \rightarrow \mathrm{A}$ change at nucleotide 1896 (G1896A), which creates a stop codon and results in loss of HBeAg synthesis. The most common core promoter mutation involves a two nucleotide substitution at nucleotides 1762 and 1764 (11). As noted, infection by a pre-core mutant of HBV or spontaneous mutation of the pre-core or core promoter region of the HBV genome during the course of chronic hepatitis caused by wild-type HBV (HBeAg-negative chronic hepatitis $B$ ) may result in reactivated chronic hepatitis B with a rise in serum HBV DNA levels and possible progression to cirrhosis (at a rate of $8-10 \%$ per year), particularly when additional mutations in the core gene of HBV are present $(12,13)$. Risk factors for reactivation include male sex and HBV genotype C. In patients with either HBeAg-positive or HBeAg-negative chronic hepatitis B, the risk of cirrhosis and of hepatocellular carcinoma correlates with the serum HBV DNA level. HBeAg negative CHB is a potentially severe disease that rapidly progress to cirrhosis and related complications (14). The course of chronic viral hepatitis is variable and unpredictable. The sequels of chronic hepatitis secondary to hepatitis B include cirrhosis, liver failure, and hepatocellular carcinoma. The 5 -year mortality rate is $0-2 \%$ in those without cirrhosis, $14-20 \%$ in those with compensated cirrhosis, and 70-86\% following decompensation (15). There is some evidence that HBV genotype $\mathrm{C}$ is associated with a higher risk of cirrhosis and hepatocellular carcinoma than other genotypes. Antiviral treatment improves the prognosis in responders.

The aim of the study is to determine the prevalence and clinical relevance of precore mutant HBV infection in patients with chronic hepatitis B, as well clinical, serological and histological patterns of the disease.

\section{MATERIAL AND METHOD}

Sixty seven patients with chronic liver disease related to HBV infection have been studied. The inclusion criteria for entering in the study were: chronic liver disease related to HBV infection without prior antiviral treatment, serum presence of HBV DNA and positive histopathological findings for chronic viral disease. Exclusion criteria were: Hepatitis $\mathrm{C}$ virus infection and alcohol abuse, HBV related chronic liver disease with undetectable HBV DNA as well as cases in whom liver biopsy was not performed. Initial evaluation includes a history and physical examination, with special emphasis on risk factors for infection or coinfection, alcohol use and family history of HBV infection or liver cancer. The common presentation was generalized weakness and malaise, impaired liver function tests and jaundice in five cases. Clinical examination included biochemical investigation and abdominal ultrasound examination. Clinical evaluation and liver biopsy were performed at the University Clinic of Gastroenterohepatology in Skopje. Laboratory tests include routine biochemistry and an assessment of liver disease through liver enzymes, prothrombin time (INR), bilirubin and serum albumin level. Detection of markers for viral infection $\mathrm{B}$, including $\mathrm{HBsAg}, \mathrm{HBeAg} / \mathrm{antiH}-$ $\mathrm{Be}$, antiHBc, and antiHBcIgM, was performed with Micro particle enzyme immunoassay (MEIA) using immunoanalyzer Axsym-Abbott. Quantification of HBV DNA was done using Amplicor monitor test with cut-off of 1000 copies $/ \mathrm{ml}$. All patients underwent a liver biopsy and consecutive histopathological analysis. The assessment of necroinflammatory activity in the liver tissue was done using the score for histopathological activity index according to Knodell.

Detection of mutations in pre-core region of HBV genome was performed with INNO-Lipa HBV preCore v8 line prober hybridization assay from Innogenetics. The biochemical, serological and molecular testing was done at the Institute for Clinical Biochemistry.

\section{RESULTS}

This study includes a total of 67 patients with chronic hepatitis B and active viral replication. Male/female ratio was 46/21. Age distribution of all patients ranged from 23 to 64 years (M.v. 36y) (Table 1). According to the severity of the disease based on clini- 
Table 1. Demographic, laboratory, virological and histological features of 67 patients with chronic hepatitis $B$

\begin{tabular}{|l|c|}
\hline Variable & Chronic hepatitis B $\left(\mathrm{N}^{\circ}\right.$ 67) \\
\hline Mean age (yrs) & $43.9 \pm 11.8$ \\
\hline Gender & 45 \\
$\quad$ Male & 22 \\
\hline Female & $128 \pm 62$ \\
\hline ALT (U/L) & $2 \times 10^{3}$ to $4 \times 10^{7}$ \\
\hline HBV DNA (copies/ml) & $3-12$ \\
\hline Knodell score & \\
\hline
\end{tabular}

cal and histopathological differentiation, the patients were divided into following groups:

- Chronic hepatitis with mild form of the disease (histology activity index according to Knodell ranged from 1 to 3 ): 13 cases

- Chronic hepatitis with moderate disease and Knodell score ranged from 4 to $8: 24$ cases

- Chronic hepatitis with high histology activity index according to Knodell (in range of 9 to 12 points) : 23 cases

- Compensated cirrhosis 7 pts

Alanin-aminotransferase (ALT) activity at baseline was $128 \pm 62 \mathrm{U} / \mathrm{L}$. According to the HBeAg/antiHBe status, we have found $25 \mathrm{HBeAg}$-positive and 42 HBeAg-negative subjects. The viral load of HBV DNA ranged from $2 \times 10^{3}$ copies $/ \mathrm{ml}$ to $4 \times 10^{7}$ copies $/ \mathrm{ml}$. The presence of fibrosis in the liver tissue was found in $34 / 67$ patients, indicating the stage of liver disease. The signs of fibrosis were identified in this extent: F1 was found in 19 patients, F3 in 8 and F4 in 7 pts. The level of viremia in both $\mathrm{HBeAg}$-positive and $\mathrm{HBe}$ Ag-negative forms as well as the total score according to Knodell, indicating the sum of necroinflammatory and fibrosis scores, are presented in Table 2. The presence of mutations in pre-core region of HBV was checked in the group of HBeAg-negative form of hepatitis B. Precore (PC) mutants were found in 38/42 (90\%). $6 / 38$ patients had wild type $\mathrm{PC}$ mutation $(\mathrm{G})$, the mutation of nt $1896 \mathrm{G}-\mathrm{A}$ was detected in $22 / 38$ patients, while $10 / 38$ patients had mixture of wild type and variant (A). The analysis of histological features of fibrosis in liver tissue showed predominant association of this finding with $\mathrm{HBeAg}$-negative patients. Moreover, the
Table 3. Histopatological findings of fibrosis in liver biopsy according to HBeAg status and precore mutations

\begin{tabular}{|l|c|c|c|}
\hline & $\begin{array}{c}\text { No signs } \\
\text { of fibrosis }\end{array}$ & $\begin{array}{c}\text { Presence of } \\
\text { fibrosis } \\
\text { (since } 1 \text { to } \\
4 \text { points) }\end{array}$ & Total \\
\hline HBeAg-positive & 21 & 4 & 25 \\
\hline HBeAg-negative & 12 & 30 & 42 \\
\hline Total & 33 & 34 & 67 \\
\hline Precore mutations & 8 & 30 & 38 \\
\hline
\end{tabular}

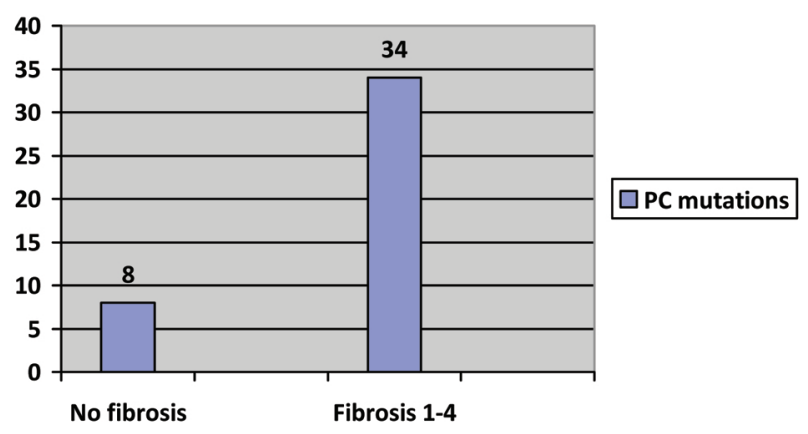

Figure 1: Prevalence of precore mutations in pts with HBeAg-negative hepatitis $B$ according to presence of fibrosis

mutations of pre-core domain have been found in all of the patients with $\mathrm{HBeAg}$-negative hepatitis and signs of fibrosis (Figure 1). These mutations are associated with more severe forms of chronic liver disease related to hepatitis B viral infection (higher score of HAI according to Knodell). The average age in the group with $\mathrm{HBeAg}$-negative hepatitis $\mathrm{B}$ is higher comparing the HBeAg-positive cases, and the presence of mutations is more prevalent in this group. All these results suggest that the occurrence of precore mutations in our patients could be related to longer duration of the disease and might be implicated in the progression of liver disease.

\section{DISCUSSION}

Chronic HBV infection is a dynamic process that may show different patterns of HBV serology and DNA replication. Chronic HBV infection can be schematically divided into following phases: the immune tolerant state, immune reactive $\mathrm{HBeAg}$-positive phase,

Table 2. Laboratory, virological and histological features according to HBeAg status

\begin{tabular}{|c|c|c|c|c|c|c|c|c|}
\hline Chronic hepatitis B & $\begin{array}{l}\text { Age } \\
\text { (years) }\end{array}$ & \multicolumn{2}{|c|}{ ALT (IU/L) } & \multicolumn{2}{|c|}{$\begin{array}{c}\text { HBV DNA } \\
\text { copies/ml (MV) }\end{array}$} & \multicolumn{2}{|c|}{$\begin{array}{l}\text { Knodell } \\
\text { HAI score } \\
\text { (MV) }\end{array}$} & \multirow{2}{*}{\begin{tabular}{|c|}
$\mathrm{N}^{\circ}$ of pts \\
25 \\
\end{tabular}} \\
\hline HBeAg-pos. & $35 \pm 10$ & $156 \pm 43$ & \multirow{2}{*}{$\mathrm{P}<0.05$} & $1.204 \times 10^{3}$ & \multirow{2}{*}{$\mathrm{P}<0.05$} & 5 & \multirow{2}{*}{$\mathrm{P}<0.01$} & \\
\hline HBeAg-neg. & $51 \pm 13$ & $116 \pm 54$ & & $67 \times 10^{4}$ & & 9 & & 42 \\
\hline
\end{tabular}


the inactive $\mathrm{HBV}$ carrier state and $\mathrm{HBeAg}$ negative chronic hepatitis B (16). By clinical point of view it is very important to distinguish the active forms of the liver disease - $\mathrm{HBeAg}$-positive and $\mathrm{HBeAg}$ negative hepatitis $\mathrm{B}$. HBeAg-positive hepatitis B is characterized by $\mathrm{HBeAg}$ positivity, HBV DNA replication, increased or fluctuating levels of aminotranspherases, moderate or severe liver necroinflammation and more rapid progression of fibrosis (17). Loss of $\mathrm{HBeAg}$ in such cases and development of anti-HBe, when it occurs spontaneously without antiviral therapy, is usually associated with a decrease in serum HBV viral load and a favorable prognosis (18). In our study group, HBeAg-positivity associated with HBV DNA replication was found in $25 / 67$ pts., indicating active viral replication. Histopathological analysis of liver biopsy of these patients showed moderate degree of necroinflammation and low level of fibrosis, suggesting ongoing liver damage, but lack of progression of the disease.

There are some patients with chronic hepatitis B who have detectable serum HBV DNA despite having persistently negative $\mathrm{HBeAg}$ (19). These patients also have evidence of active liver disease on liver biopsy suggesting development of so called HBeAg-negative chronic hepatitis. HBeAg-negative chronic hepatitis B (CHB) is a potentially severe and progressive form of CHB prevailing in Southern Europe and the Mediterranean Area (20). HBeAg-negative chronic hepatitis B is characterized by periodic reactivation leading to active hepatitis. The main features of this form are fluctuating levels of HBV DNA and aminotransferases activity, high rate of progression and low rates of spontaneous disease remission (21). A lack of $\mathrm{HBeAg}$ in the blood and possible normal level of aminotransferase activity could be confusing in differentiation of patients with HBeAg-negative hepatitis and inactive carrier state, and a careful assessment of such patients is needed to distinguish these two different forms of HBV infection due to similar biochemical patterns. Among our patients HBeAg-negative hepatitis is predominant. Analysis of biochemical and virological parameters has shown that alanin-aminotransferase activity was higher in $\mathrm{HBeAg}$-positive patients, as well as the level of viremia. However, the histopathological features of liver damage were more prominent in $\mathrm{HBeAg}$-negative group. The mean value of total HAI according to Knodell was 9 , and signs of fibrosis have been identified in 30 patients, comparing to 4 pts with $\mathrm{HBeAg}$-positive hepatitis. Lower level of ALT in HBeAg-negative patients, despite more intense histology features, can be explained by specific biochemical patterns of aminotransferases in this form of hepatitis, characterized by normal ALT level and intermittent flares, implying progressive course.
The normal HBeAg synthesis alters due to precore and core promoter mutations in the HBV DNA resulting with a lack of e-antigen in the blood. The process of $\mathrm{HBeAg}$ synthesis begins with initiation of transcription at the ATG codon at location 1814 (22). The precore mutation involves a G-to-A base pair substitution at nucleotide 1896 in the precore region of the HBV genome. This mutation transforms codon 23 in the mRNA from TGG to a TAG stop codon. The consequence of the creation of the stop codon is the formation of a truncated 28 amino-acid peptide and thus the formation of normal HBeAg is completely halted. Thus, the mutations in the precore region (PC), such as G1896A, generated a stop codon and halt translation of $\mathrm{HBeAg}$ (23). Failure to produce HBeAg might help the HBV to evade immune detection. In clinical practice, the diagnosis of $\mathrm{HBeAg}$-negative chronic hepatitis B is generally made by identifying a high HBV DNA load in HBeAg-negative patient, although there is no clear viral load 'cutoff' (24).

The patients with HBeAg-positive hepatitis in our study group belong to younger age comparing to $\mathrm{HBe}-$ Ag-negative patients (average age $35 \pm 10$ versus $51 \pm$ 13 years respectively). More advanced stage of liver disease in HBeAg-negative patients could be a consequence of longer duration of HBV infection or more severe clinical course of the disease. As we do not know the time of initial infection, we are not able to analyze or comment the impact of duration, but we could suppose that the higher age is probably associated with long-term course of HBV related liver disease. Moreover, long-term persistence of viral replication could allow emergence of mutant strains of hepatitis B, responsible for more aggressive clinical disease. Actually, during the immune clearance phase of hepatitis $\mathrm{B}$, a selection of $\mathrm{HBeAg-negative} \mathrm{mutant} \mathrm{could} \mathrm{occur} \mathrm{as} \mathrm{a}$ consequence of increased immune pressure on the wild-type strain of $\mathrm{B}$ virus. We have detected mutations in precore region of $\mathrm{HBV}$ in 38 cases with HBeAg-negative hepatitis. The majority of them have presence of fibrosis in liver tissue, meaning more advanced stage of the disease. HBeAg-negative hepatitis B develops after long-term persistence of HBV infection but sometimes, it could appear from the beginning of the disease. Although the increased prevalence of advanced fibrosis in patients with $\mathrm{HBeAg}$-negative chronic hepatitis B may be partially explained by the older age of these patients (and thus the longer duration of infection), some studies have suggested that increased virulence of these mutant strains may lead to more aggressive clinical disease. Our results show that HBeAg-negative hepatitis is more prevalent in older age and is associated with fibrosis rather than HBeAg-positive hepatitis. Very high percentage of precore mutations in this 
group could be explained by longer duration of HBV infection and its increased virulence may be responsible for more aggressive disease.

For precise differentiation of the disease, an assessment of liver damage through a liver histology is also needed. Identification of viral mutations is clear confirmation about the nature of the disease and has a clinical relevance in regard of the treatment and prognosis of such patients. HBeAg negative CHB is a potentially severe disease that rapidly progress to cirrhosis and related complications. Many experts consider infection with $\mathrm{HBeAg}$-negative viral strains to correlate with a poor prognosis when compared with wild-type infection. The genetic studies play important role in understanding the disease course and will be necessary in the management of the disease in the near future.

\section{CONCLUSION}

Our data show that the majority of the patients in our study group belong to the HBeAg-negative chronic hepatitis. Among patients with a loss of e-antigen, the presence of mutations on the precore region of HBV genome is extremely high. Patients with HBeAg-negative hepatitis B have more severe histological damage comparing to $\mathrm{HBeAg}$-positive patients. The presence of precore mutations is associated with high incidence of fibrosis in liver tissue. There is statistically significant difference in the level of ALT activity and HBV viral load in both groups. Older age is predominant in HBeAg-negative hepatitis, suggesting a likelihood of longer duration of the disease. All these data underline a crucial role of molecular events in the viral genome having significant implications on the clinical course of hepatitis B.
Abbreviations
CHB - chronic hepatitis B
HBV - hepatitis B virus
HBV DNA - hepatitis B deoxyribonucleic acid
HBeAg - hepatitis B e antigen
HBsAg - hepatitis B surface antigen

\title{
Sažetak
}

\section{KLINIČKI ZNAČAJ PRECORE MUTACIJA HEPATITIS B VIRUSA KOD HRONIČNOG OBOLJENJAJETRE}

\author{
Chaloska Ivanova Viktorija, ${ }^{1}$ Koloska Valentina, ${ }^{2}$ Genadieva Dimitrova Magdalena, ${ }^{1}$ \\ Todorovska Beti, ${ }^{1}$ Curakova Elena ${ }^{1}$ \\ ${ }^{1}$ University Clinic of Gastroenterohepatology, Clinical Centre, Skopje, Republic of Macedonia \\ ${ }^{2}$ Institute of Clinical Biochemistry, Clinical Centre, Skopje, Republic of Macedonia
}

Uvod: Hepatitis B je jedan od najčešćih etioloških faktora za hronično oboljenje jetre širom sveta. Nedavne studije ukazuju na značajnu uogu genetske raznovrsnosti virusa u prirodnom toku hepatitisa B. Hepatitis $\mathrm{B}$ e-antigen negativan tip hroničnog hepatitisa je povezan sa mutacijama u precore regionu virusa. Cilj ove studije je da identifikuje precore mutacije $u$ virusnom genomu među pacijentima sa hroničnim hepatitisom B i da evaluira kliničke oblike hroničnog oboljenja jetre vezane za tip hepatitis B virusne infekcije. Metode: 67 pacijenata sa hepatitisom B je uključeno u studiju. $U$ cilju evaluacije kliničkih oblika hroničnog oboljenja jetre sa hepatitis B virusnom infekcijom, biohemijska i virusološka istraživanje su izvršena, kao i kvantifikacija viremije u serumu. Svim pacijentima izvedena je biopsija jetre i semikvantifikacija nekroinflamacije $\mathrm{i} / \mathrm{ili}$ fibroze prema Knodell skoru. U grupi e-antigen-negativnh pacijenata, izvedena je molekularna analiza u cilju otkrivanja prisustva mutacije u precore regionu virusa. Rezultati: Ispitivana grupa je podeljena na 25 $\mathrm{HBeAg}$ pozitivnih i $42 \mathrm{HBeAg}$ negativnih ispitanika.
Aktivnost alanin-aminotransferaze i nivo virusa u krvi bili su veći u HBeAg-pozitivnih ( $p<0,05$ ), ali su prosečna starosna dob i indeks histološke aktivnosti bili znatno veći u HBeAg negativnih pacijenata $(p<0,01)$. Precore mutacije su nađene u 38 od 42 bolesnika $s$ HBeAg negativnim hepatitisom (90\%). Fibroza je pronađena u $30 / 38$ slučaja s mutacijama.

Diskusija: Mutacije u precore regiji HBV u HBe$\mathrm{Ag}$ negativnih pacijenata bili su češći u starijoj dobi te su povezani s visokom stopom fibroze u tkivu jetre, što odgovara više uznapredovalom stadijumu bolesti. To bi moglo biti posledica dužeg trajanja HBV infekcije ili težeg kliničkog toka bolesti. Zaključak: Naši rezultati sugerišu na to da je precore mutacija visoko odgovorna za razvoj heptitis B e antigen-negativnog hroničnog oboljenja jetre kod naših pacijenata. Ove mutacije su povezane sa mnogo težim oblicima oboljenja jetre i strarijom grupom pacijenata.

Ključne reči: Hepatitis B virus, $\mathrm{HBeAg}$, HBV DNA, prejedarna mutacija, hronični aktivni hepatitis B. 


\section{REFERENCES}

1. Fattovich G. Natural history and prognosis of hepatitis B. Semin Liver Dis. 2003; 23(1): 47-58.

2. Fattovich G, Bortolotti F, Donato F. Natural history of chronic hepatitis B: special emphasis on disease progression and prognostic factors. J Hepatol. 2008; 48(2): 335-52.

3. Fattovich G, Olivari N, Pasino M, D'Onofrio M, Martone E, Donato F. Long-term outcome of chronic hepatitis B in Caucasian patients: mortality after 25 years. Gut 2008; 57(1): 84-90.

4. Ganem D, Prince AM. Hepatitis B virus infection natural history and clinical consequences. N Engl J Med. 2004; 350(11):1118-29.

5. Maddrey WC. Hepatitis B: An important public health issue. J Med Virol. 2000; 61(3): 362-6.

6. Brunetto M, Oliveri F, Colombatto P, et al. Hepatitis B Surface Antigen Serum Levels Help to Distinguish Active From Inactive Hepatitis B Virus Genotype D Carriers. Gastroenterology. 2010; 139(2): 483-90.

7. Fattovich G, Stroffolini T, Zagni I, Donato F. Hepatocellular carcinoma in cirrhosis: incidence and risk factors. Gastroenterology 2004;127(5 Suppl 1): S35-S50.

8. Hadziyannis SJ, Papatheodoridis GV. Hepatitis B e antigen negative chronic hepatitis B - natural history and treatment. Semin Liver Dis. 2006; 26(2): 130-41.

9. Rizzetto M, Ciancio A. Chronic HBV-related liver disease. Mol Aspects Med. 2008; 29(1-2): 72-84.

10. Hadziyannis SJ, Vassilopoulos D: Hepatitis B e antigen-negative chronic hepatitis B. Hepatology 2001; 34(4 Pt1): $617-24$.

11. Locarnini S, McMillan J, Bartholomeusz A: The hepatitis B virus and common mutants. Semin Liver Dis. 2003; 23(1): 5-20.

12. Hunt CM, McGill JM, Allen MI, Condreay LD: Clinical relevance of hepatitis B virus mutations. Hepatology. 2000; 31(5): 1037-44.

13. Parekh S, Zoulim F, Ahn SH, et al. Genome replication, virion secretion, and e antigen expression of naturally oc- curring hepatitis B virus core promoter mutants. J Virol. 2003; 77(12): 6601-12.

14. Martinot-Peignoux M, Boyer N, Colombat M, et al. Serum hepatitis B virus DNA levels and liver histology in inactive HBsAg carriers. J Hepatol 2002; 36(4): 543-6.

15. Lok AS, McMahon BJ. Chronic hepatitis B-An update. Hepatology. 2009; 50(3): 1-36.

16. EASL Clinical Practice Guidelines: Management of chronic hepatitis B virus infection. Journal of Hepatology. 2012; (57): 167-85.

17. Hadziyannis SJ, Vassilopoulos D. Hepatitis B e antigen-negative chronic hepatitis B. Hepatology. 2001; 34(4Pt1): 617-24.

18. Gerlich W. Medical Virology of Hepatitis B: how it began and where we are now. Virology Journal. 2013; 10:239.

19. Liaw YF, Brunetto MR, Hadziyannis S. The natural history of chronic HBV infection and geographical differences. Antivir Ther. 2010; 15 Suppl 3: S25-33.

20. Zarski JP, Marcellin P, Leroy V, et al. Characteristics of patients with chronic hepatitis B in France: predominant frequency of HBe antigen negative cases. J Hepatol 2006; 45(3): 355-60.

21. Liu Y, Zhong Y, Zou Z, et al. Features and clinical implications of hepatitis B virus genotypes and mutations in basal core promoter/precore region in 507 Chinese patients with acute and chronic hepatitis B. J Clin Virol. 2010; 47(3): 243-7.

22. Parekh S, Zoulim F, Ahn S, et al. Genome replication, virion secretion, and e antigen expression of naturally occurring hepatitis B virus core promoter mutants. J Virol. 2003; 77(12): 6601-12.

23. Ahn S, Kramvis A, Kawai S, et al. Sequence variation upstream of precore translation initiation codon reduces hepatitis B virus e antigen production.Gastroenterology. 2003; 125(5): 1370-8.

24. Chen YC, Huang SF, Chu CM, Liaw YF. Serial HBV DNA levels in patients with persistently normal transaminase over 10 years following spontaneous $\mathrm{HBeAg}$ seroconversion. J Viral Hepat. 2012;19(2):138-46.

\section{Correspondence to/Autor za korespondenciju}

Viktorija Chaloska Ivanova, $\mathrm{MD}, \mathrm{PhD}$

University Clinic of Gastroenterohepatology, Clinical Centre, Skopje, Republic of Macedonia Vodnjanska 17, 1000 Skopje, Macedonia Tel: +389 70248 918, +38923068129

E-mail: viktorijacaloska@gmail.com 